\title{
The Bibliographer Working in a Broad Area of Knowledge
}

Dr. Fussler is director, University of Chicago Library.

$\mathrm{M}^{\mathrm{s}}$ Y REMARKS in this paper are directed toward the activities of the bibliographer working in a broad subject area such as the'humanities, the social sciences, the physical, or the biological sciences. It is essential that we define the situation to be discussed and the meaning of the terms to be used. To this end our comments will be limited to the bibliographical problems of the large, university, research library. I venture to say that (a) the most important, and (b) one of the most difficult activities in such a library is the selection of books and other materials to be added to and to be withdrawn from the collections of such a library.

It is the most important because it is the most permanent aspect of a research library's operations, and because errors of commission or omission in this activity are most expensive and most difficult to correct. Administrative organizations, procedures, good or bad public services, and good or inefficient personnel may have some permanent effects, but in these areas the deficiencies of the past can in many, though not all, instances be corrected without prohibitive loss of time or money. These are, in a relative sense, the ephemera of librarianship. Even buildings can be, and are, superseded by new and better ones. But the book collection-excluding losses, physical decay and discarding-stays. If well built, much

${ }^{1}$ Paper presented at the meeting of the University Libraries Section, A.C.R.L., Jan. 2x, 1949, Chicago. of it increases in value as the years go by; if poorly built, remedial action becomes increasingly and appallingly expensive as the years go by. What could once have been had for two dollars, is now five, ten, fifteen or twenty - and I speak of the ordinary grist of the research library-not the rare or unique materials.

Building the book collection in a university research library is one of the most difficult of all library activities because highly selective judgments must be made. To make selective judgments well requires both thought and knowledge. Neither of these are overly plentiful-even in the scholarly world. Books, unfortunately perhaps, cannot be divided as good or bad, useful or not useful. Such items must always be qualified: good for what? or for whom? useful for what? or for whom?

Our fundamental difficulty, in large measure, grows out of the characteristic pattern of use of a research collection. If we draw the curve of use plotted against the number of volumes in a collection, it is apparent that at one end of the curve we will have a very few books used many times each day, week, or month. The rate of use will fall rapidly depending upon the type of research, the extent of the research literature and other factors. The bulk of use will be covered by a relatively small collection. Let us say, for most areas, a few thousand or few tens of thousands of books will supply a very high percentage of the demand. It is only beyond this point in the provision of materials that we 
begin to have the general characteristics of a research library; then we have the rare, the recondite, and the little-used-but indispensable-document. Our curve becomes asymptotic and the individual book in the vast bulk of our collections is used only occasionally-if at all. When the curve of use is horizontal the importance of selective judgments becomes more obvious. Other criteria than use must be brought to bear on selection.

I use "must" advisedly, for selection is vital; none of us has the resources to buy the materials we might at some time want, for scholars have the reputation-not entirely undeserved - of wanting almost anything at some time. Therefore we must buy those that are most "important" or those that we "need" most. There is a difference, for both need and importance have temporal aspects that introduce additional hazards for the bibliographer. Further, need must be defined in terms other than use or loans as we have just tried to demonstrate. We must consider the distinction of the author, the importance of the edition, the school of thought represented, the special content, the geographic area, and many other qualities. These factors must be delicately balanced against the library's existing resources, the importance or nature of the research being conducted, the teaching or research trends of the university, and-by no means least-the funds available. Selection must rely in the future more on carefully appraised probabilities of use and less on intuitive, or other possibilities of use. Since the universe of available - and desirable-books is still very large, the purchase of one book means not only that a positive decision has been reached, but negative ones are made at the same time, for the same money cannot be spent twice. And funds in most libraries are always insufficient to meet the demand. In the years to come, withdrawals of ma- terials from scholarly libraries will almost certainly become as important as additions now are. The bibliographical judgments for these activities will be even more difficult.

These are some of the more general aspects of bibliography at the research level that indicate, I trust, the importance and the difficulty of the task of the bibliographer as we are using the word here. I have yet to show why I think a bibliographer working in a broad subject area is important to a university library. To so indicate will require that I be somewhat specific on problems of selection and acquisition of library materials in a university library as they appear to me. My observations are obviously subjective and I can support most of them with only meagre, if any, objective data. I present them with no little hesitation and in doing so acknowledge my debt to my colleagues and predecessors.

\section{Traditional Book Selection}

The tradition of book selection in most universities may be described somewhat as follows. By some device or other, the bulk of the available book fund for the year was broken up into departmental allotments, the size of which varied according to various ingenious formulae or weighted factors such as the extent of existing library resources, the amount of publishing being done in the field, the cost of publications in the particular field, numbers of graduate and undergraduate students, numbers of faculty members, and the amount allotted last year, to name a few of the more common factors. The librarian kept a reserve to be used to cover general acquisitions, and to help with major departmental purchases. Each department then appointed a library advisor who either ordered materials on his own initiative or on the recommendation of his departmental colleagues, or the departmental chairman 
assumed this role. The difficulties of this scheme are known so well that a bare listing of some of them will suffice: borderline materials tend to be omitted, the library advisor or a segment of a department can acquire materials in a very narrow or restricted field to the exclusion of important basic materials, the advisors' bibliographical judgments vary greatly in quality from excellent to poor, there tends to be insufficient attention given by some, while others are overzealous. Some departments finding an accumulation of unspent funds at the end of the fiscal year will spend hastily. The cost of each item rather than its quality looms higher than it should because of the diminution of funds it creates for the balance of a year. There is a lack of continuity in acquisition policy, for the advisors change from year to year, etc. Virtues exist in the plan, but are more difficult to ascertain and to describe. Once the allocations are made the librarian is free of worry; the departments know where they stand on book funds and can plan accordingly; they can buy only what they want and thus stretch their funds more effectively over the requirements for their current research.

Now I do not wish to be misunderstood. The library exists only to serve its university now and in the future. It may have some obligation as a conservator of knowledge, but its essential role must be as stated. In such a role the faculty's bibliographical knowledge is not only important, but should be recognized as extensive and absolutely vital to the growth of the library. But the faculty and the university as $a$ whole are important and the needs of future faculties must also be given some consideration. Perhaps this may be put more clearly by saying that I think there should be an acquisition policy and that it should be a university policy in which the departments concur. Such a policy of acquisition would, I think, be different than an amalga- mation of the uncoordinated policies of most library advisors.

Since such a general policy cannot be static it calls for constant oversight, review, adjustment, amendment and interpretation. It may call for more or less bibliographical activity in some areas of minor or diverse current interest where faculty activity is either dispersed or is not high.

\section{Cioncept of the Bibliographer}

Perhaps my concept of the bibliographer in a broad area may now be somewhat clearer. $\mathrm{He}$ is the principal coordinating officer of bibliographical activity in his subject area. He deals with a broad area because no man can deal with all knowledge, and the subject interrelationships of an area are extremely important. He has a genuine interest in libraries and their problems. He knows the content of a general scholarly field well; he is a scholar in his own right; his interests must be broad and catholic; he must know books, book values, dealers, and dealers' specialties; his bibliographic judgments must be sound and reliable; he must enjoy reading dealers' catalogs and examining secondhand books; he must know the faculty of his area and what they are working upon; he must know where their judgment of books can supplement his and where it is apt to be deficient.

We believe he should not and could not displace the faculties' bibliographical work. The difficulties of acquisition in highly specialized subject fields and in many languages require highly specialized knowledge that only individual faculty members will possess. But the bibliographer can advise on general policy and stimulate faculty activity. He ought to know what is being ordered in his general subject area, and being a man of erudition and immense tact, he should be able to question unsound faculty recommendations, and convince the faculty member that his recommendation, 
in fact, is unsound for reasons of cost, coverage, unnecessary duplication, etc.

$\mathrm{He}$ can largely ignore those areas where he knows the literature is being properly covered by members of the faculty or by members of the library staff, and concentrate especially on those areas which are important and yet which are not receiving such attention. Since his talents are many, he can and does anticipate many of the more conventional needs of the faculty because he sees the trade bibliographies first. $\mathrm{He}$ fills in the lacunae of years gone by, because he reads the catalogs promptly. He will take the time to canvass systematically the lacunae of special subjects; this the faculty will do only occasionally if at all, for in general, faculty members tend to give most of their attention to current materials.

$\mathrm{He}$ can both stabilize and alter acquisition policy as the university's needs may require and he can appraise the importance of major acquisitions within the framework of that policy. Since all of this would kill any man who devoted himself to it all day long, we think he should give about one half of his time to teaching or to research in a department in his general area. Thus he can also serve the library in a critical liaison capacity, bringing to the library's councils the views of a faculty-since he is one of them-and he can also bring to his fellow faculty members the problems of the library since he is also a librarian. (A dichotomy is implied here which I think should not and may not exist.) This, of course, is not the only possible pattern of relationships. There may be circumstances under which the bibliographer may divide his time between bibliography and library administration or service in some other special field.

Relying thus heavily on his judgment, the funds at his disposal should be made extensive, and the departmental allocations may be minimized in consequence. The university, instead of buying books according to the balances in allocated funds, can more nearly acquire materials that the university needs. The funds become more fluid. The faculty members wanting expensive or borderline materials can pass their requests on to the bibliographer without fear of its penalizing their allocations. Since he is in a very real sense one of them, he will surely be sympathetic. When it turns out that he is not, his voice is more than likely to carry a convincing authority with it.

As research and literature grow and become more complex, the research library becomes increasingly vital to the university, but its problems of acquisition grow and become complex also. If we are to solve them, we need diverse and able skills to help us. These skills in a university are to be found in the faculty, the library staff, and even among the students. If all the talents available are to be brought to bear on the problem, as I think they should, a high level coordinating responsibility is created. The director of the library, while responsible for general policy and its interpretation, cannot, under most circumstances at least, handle so large a task alone. The bibliographer working in a broad area of knowledge and advising the director represents, to my mind, the most effective way of achieving the necessary integration and coordination of acquisition policy in a large and complex university library. 